\title{
Chrysanthemum morifolium inhibits inflammatory responses in IFN- $\gamma$ and LPS-induced mouse peritoneal macrophages
}

\author{
Ho-Jeong $\mathrm{Na}^{1}$, Dong Seok $\mathrm{Cha}^{1}$, Sora Jeon ${ }^{1}$, Youngmin $\mathrm{Bu}^{1}$, Wonhwan Jeong ${ }^{2}$ and Hoon Jeon ${ }^{1, *}$ \\ ${ }^{I}$ Department of Oriental Pharmacy, College of Pharmacy, Woosuk University, Jeonbuk, Republic of Korea; \\ ${ }^{2}$ Gochang GukHwa festival Committee, Gochanggun, Chonbuk, Republic of Korea
}

\begin{abstract}
SUMMARY
Chrysanthemum morifolium (CM) is a herb widely used in medicine for the treatment of a variety of diseases. In this study, using mouse peritoneal macrophages, we have examined whether $\mathrm{CM}$ affects nitric oxide (NO), tumor necrosis factor (TNF)- $\alpha$ and interleukin (IL)- 6 induced interferon (IFN)- $\gamma$ and lipopolysaccharide (LPS). CM inhibits IFN- $\gamma$ and LPS-induced NO in dose dependent manner. We also found that CM inhibits pro-inflammatory cytokine, TNF- $\alpha$ and IL-6. The expression of cyclooxygenase- 2 was reduced by CM. These finding means that CM can be used in controlling macrophages-mediated inflammatory disease.
\end{abstract}

Key words: Chrysanthemum morifolium; Nitric oxide; TNF- $\alpha$; IL-6; COX-2

\section{INTRODUCTION}

The dried flower-heads of Chrysanthemum morifolium (CM) (Compositae) are an oriental drug, which has been used for the treatment of eye disease in Korea and China. They have also been used as an herbal tea in Chinease folklore and are known as "Ju Hua". They have been found to possess antibacterial, antifungal, antiviral, antispirochetal, and antiinflammatory activities (Jiangsu New Medical College, 1977). Macrophages are a first line of defence against microbial invaders and malignancies by nature of their phagocytic, cytotoxic and intracellular killing capacities (Adams and Hamilton, 1984). Macrophage activation by lipopolysaccharide (LPS), the major component of gram-negative bacteria cell wall, results in the release of several inflammatory

*Correspondence: Hoon Jeon, Department of Oriental Pharmacy, College of Pharmacy, Woosuk University, Jeonbuk, Republic of Korea. Tel: +82-63-290-1577; Fax: +82-63-290-1576; E-mail: hoonj6343@hanmail.net mediators such as nitric oxide $(\mathrm{NO})$ and the proinflammatory cytokines, tumor necrosis factor- $\alpha$ (TNF- $\alpha$ ) and interleukin (IL)-6 (Schimmer and Parker, 2001). The physiologic or normal production of NO from phagocytes is beneficial for the host defense against microorganism, parasites, and tumor cells (Thiemermann and Vane, 1990). However, overproduction of NO can be harmful and result in septic shock, neurologic disorders, rheumatoid arthritis, and autoimmune diseases (Thiemermann and Vane, 1990; Evans, 1995; O'Shea et al., 2002). Therefore, inhibition of NO production is a very important therapeutic target in the development of anti-inflammatory agents.

The pro-inflammatory cytokine, TNF- $\alpha$ regulates systemic responses to microbial infection or tissue injury (Evans, 1995). TNF- $\alpha$ induces other inflammatory cytokines such as IL-1, IL-2, IL-6, IL-18 and granulocyte-macrophage colonystimulating factor. The involvement of TNF- $\alpha$ as a pathogenic factor has been documented in 
several immunoinflammatory diseases, including arthritic diseases, inflammatory bowel diseases, type 1 diabetes mellitus, multiple sclerosis, and Guillain-Barre syndrome (O'Shea et al., 2002). In patients with rheumatoid arthritis, juvenile idiopathic arthritis and ankylosing spondylitis, for example, neutralizing anti-TNF antibodies and soluble TNF- $\alpha$ receptors are powerful means of controlling disease activity (Gorman et al., 2002). IL-6 is macrophage-or monocyte-related cytokine (Sradnyk, 1997). It is essential for the inflammatory response to pathogenic germs or toxicants (Liew, 2003).

$\mathrm{NO}$ and pro-inflammatory cytokine are well known to be important mediators of acute and chronic inflammation (Park et al., 2000)/and are synthesized by cyclooxygenase (COX) enzymes. There are two isoform of COX, constitutively expressed COX-1 and the inducible isoform COX-2 (Kanazawa, et al., 1995). COX-2 is upregulated in response to inflammatory and pro-inflammatory mediators and their products can influence many aspects of inflammatory cascade.

In the present study, we show that CM significantly inhibited LPS and IFN- $\gamma$-induced NO production in a dose-dependent manner. Furthermore, $\mathrm{CM}$ inhibited TNF- $\alpha$ and IL- 6 production. The expression of COX-2 protein was markedly decreased. Thus, $\mathrm{CM}$ may be useful in certain type of inflammation, allergy and infectious disorders.

\section{MATERIALS AND METHODS}

\section{Reagents}

Murine $\operatorname{rIFN}-\gamma\left(1 \times 10^{6} \mathrm{U} / \mathrm{ml}\right)$ was purchased from Pharmingen (Mnchen, Germany). LPS and sodium nitrite were purchased from Sigma (St. Louis, MO). Recombinant TNF- $\alpha$, biotinylated TNF- $\alpha$ and antimurine TNF- $\alpha$ were purchased from R \& D system Inc, USA. Recombinant IL-6, biotinylated IL- 6 and anti-murine IL-6 were purchased from Pharmingen. Thioglycollate (TG) was purchased from Difco Laboratories (Detroit, MI). $0.4 \mu \mathrm{m}$ syringe filter and tissue culture plates of 96 wells, 4 wells and $100 \mathrm{~mm}$ diameter dishes were purchased from Nunc (Naperville, IL). DMEM containing L-arginine (84 mg/l), Hank's balanced salt solution (HBSS), fetal bovine serum (FBS), and other tissue culture reagents were purchased from Life Technologies (Grand Island, NY). Male C57BL/6 mice were purchased from Damul Science Co. (Daejeon, Republic of Korea).

\section{Peritoneal macrophages culture}

TG-elicited macrophages were harvested 34 days after i.p. injection of $2.5 \mathrm{ml} \mathrm{TG}$ to the mice and isolated, as reported previously (Chung et al., 2002). Using $8 \mathrm{ml}$ of HBSS containing $10 \mathrm{U} / \mathrm{ml}$ heparin, peritoneal lavage was performed. Then, the cells were distributed in DMEM, which was supplemented with $10 \%$ heat-inactivated FBS, in 4-well tissue culture plates $\left(2.5 \times 10^{5}\right.$ cells/well $)$ incubated for $3 \mathrm{~h}$ at $37^{\circ} \mathrm{C}$ in an atmosphere of $5 \%$ $\mathrm{CO}_{2}$, washed three times with HBSS to remove non-adherent cells, and equilibrated with DMEM that contained $10 \%$ FBS before treatment.

\section{Preparation of CM}

The plant sample was obtained from Gochang GukHwa festival Committee (Gochanggun, chonbuk, Republic of Korea). The dried samples $(250 \mathrm{~g})$ were extracted with $6.72 \mathrm{ml}$ of $85 \%$ methanol for $2 \mathrm{~h}$ at room temperature with ultrasonic waves. This step was repeated with sediment. The methanol extracts (total of $6,250 \mathrm{ml}$ ) were concentrated into $6.72 \mathrm{~g}$ plant materials using a Rotary evaporator. An extract of $\mathrm{CM}$ was lyophilized and kept at $4^{\circ} \mathrm{C}$. Dilutions were made in distilled water then filtered through $0.45 \mu \mathrm{m}$ syringe filter.

\section{Measurement of nitrite concentration}

Peritoneal macrophages $\left(2.5 \times 10^{5}\right.$ cells/well) were cultured with various concentrations of $\mathrm{CM}$. The cells were then stimulated with rIFN- $\gamma(20 \mathrm{U} / \mathrm{ml})$. After $6 \mathrm{~h}$, the cells were finally treated with LPS (10 $\mu \mathrm{g} / \mathrm{ml})$. NO synthesis in cell cultures was measured 
by a microplate assay method, as previously described (Chung et al., 2002). To measure nitrite, $100 \mu \mathrm{l}$ aliquots were removed from conditioned medium and incubated with an equal volume of Griess reagent ( $1 \%$ sulfanilamide/ $0.1 \% N$-(1-naphtyl)ethylenediamine dihydrochloride $\left./ 2.5 \% \mathrm{H}_{3} \mathrm{PO}_{4}\right)$ at room temperature for $10 \mathrm{~min}$. The absorbance at $540 \mathrm{~nm}$ was determined by an automatic microplate reader. $\mathrm{NO}_{2}^{-}$was determined by using sodium nitrite as a standard. The cell-free medium alone contained 5 to $9 \mu \mathrm{M}$ of $\mathrm{NO}_{2}^{-}$. This value was determined in each experiment and subtracted from the value obtained from the medium with peritoneal macrophages.

\section{Western blot analysis}

Peritoneal macrophages $\left(5 \times 10^{6}\right.$ cells/well) were pretreated with various concentrations $\mathrm{CM}$. The cells were then incubated with for $6 \mathrm{~h}$ with rIFN- $\gamma$ $(20 \mathrm{U} / \mathrm{ml})$. They were finally stimulated with LPS $(10 \mu \mathrm{g} / \mathrm{ml})$ for $24 \mathrm{~h}$. Whole cell lysates were made by boiling peritoneal macrophages in sample buffer $(62.5 \mathrm{mM}$ Tris- $\mathrm{HCl}$, pH 6.8, 2\% sodium dodecyl sulfate (SDS), 20\% glycerol, and 10\% 2mercaptoethanol). Proteins in the cell lysates were then separated by $10 \%$ SDS-polyacrylamide gel electrophoresis and transferred to nitrocellulose paper. The membrane was then blocked with $5 \%$ skim milk in phosphate-buffered saline (PBS)Tween-20 (Sigma) for $1 \mathrm{~h}$ at room temperature and then incubated with anti-COX-2 antibodies. After washing in with PBS containing $0.05 \%$ tween-20 three times, the blot was incubated with secondary antibody for $1 \mathrm{~h}$ and the antibody-specific proteins were visualized by the enhanced chemiluminesence detection system according to the recommended procedure (Amersham Corp. Newark, NJ).

\section{Assay of cytokine release}

Peritoneal macrophages $\left(2.5 \times 10^{5}\right.$ cells/well $)$ were incubated with rIFN- $\gamma(20 \mathrm{U} / \mathrm{ml}), \mathrm{CM}, \mathrm{rIFN}-\gamma$ plus $\mathrm{LPS}(10 \mathrm{mg} / \mathrm{ml})$ and $\mathrm{rIFN}-\gamma$ plus various concentrations of CM for $24 \mathrm{~h}$. Then the amount of TNF- $\alpha$ and
IL-6 secreted by the cells were measured by a modified enzyme-linked immunosorbent assay (ELISA), as described previously (Jeong et al., 2003). ELISA (TNF- $\alpha$ and IL-6) was carried out in duplicate in 96-well ELISA plates coated with each of $100 \mu \mathrm{l}$ aliquots of anti-human TNF- $\alpha$ and IL-6 monoclonal antibodies at $1.0 \mu \mathrm{g} / \mathrm{ml}$ in PBS at $\mathrm{pH}$ 7.4 and was incubated overnight at $4^{\circ} \mathrm{C}$. The plates were washed in PBS containing $0.05 \%$ Tween-20 and blocked with PBS containing 1\% BSA, 5\% sucrose and $0.05 \% \mathrm{NaN}_{3}$ for $1 \mathrm{~h}$. After additional washes, sample or TNF- $\alpha$ and IL- 6 standards were added and incubated at $37^{\circ} \mathrm{C}$ for $2 \mathrm{~h}$. After $2 \mathrm{~h}$ incubation at $37^{\circ} \mathrm{C}$, the wells were washed and then each of $0.2 \mathrm{mg} / \mathrm{ml}$ of biotinylated anti-mouse TNF-a and IL- 6 was added and again incubated at $37^{\circ} \mathrm{C}$ for $2 \mathrm{~h}$. After washing the wells, avidinperoxidase was added and plates were incubated for $20 \mathrm{~min}$ at $37^{\circ} \mathrm{C}$. Wells were again washed and ABTS substrate was added. Color development was measured at $405 \mathrm{~nm}$ using an automated microplate ELISA reader. A standard curve was run on each assay plate using recombinant TNF- $\alpha$ and IL- 6 in serial dilutions.

\section{Statistical analysis}

Results were expressed as the mean \pm S.E.M. of independent experiments, and statistical analysis was performed by one-way analysis of variance (ANOVA) to express the difference among the groups.

\section{RESULTS}

\section{Effects of $\mathrm{CM}$ on cell viability}

To determine the effects of $\mathrm{CM}$ on viability of mouse peritoneal macrophages, we carried out MTT assay. When we treated the cells with CM $(100 \mu \mathrm{g} / \mathrm{ml})$, it had no effect on cell viability (Fig. 1).

\section{Inhibitory effects of CM on NO production}

To determine the effect of $\mathrm{CM}$ on the production of NO by mouse peritoneal macrophages, we pretreated the cells with various concentration CM $(1,10$ and 


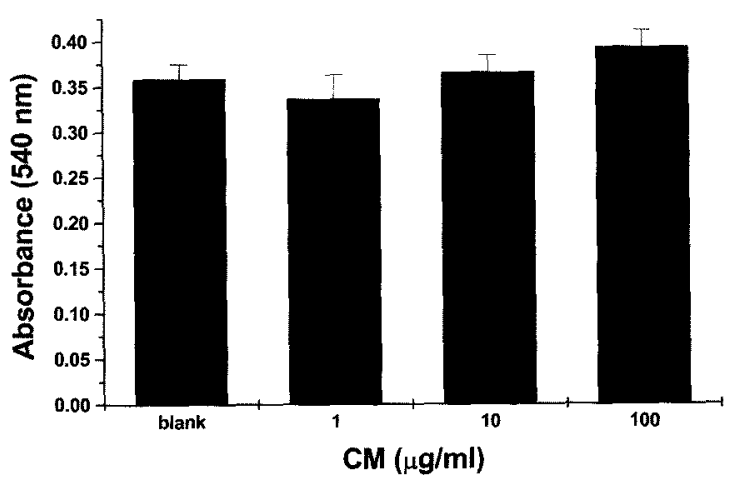

Fig. 1. Effect of $C M$ on the cell viability. Cell viability was evaluated by MTT colorimetric assay $48 \mathrm{~h}$ after $\mathrm{CM}$ treatment in peritoneal macrophages. Values are the mean \pm S.E.M. of three independent experiments duplicate in each run.

$100 \mu \mathrm{g} / \mathrm{ml}$ ). And then we stimulated them with rIFN- $\gamma(20 \mathrm{U} / \mathrm{ml})$ and LPS $(10 \mu \mathrm{g} / \mathrm{ml})$. The resultant NO production was determined by detecting nitrite concentrations in the cell supernatants after $48 \mathrm{~h}$ treatment. When mouse peritoneal macrophages were primed for $6 \mathrm{~h}$ with murine rIFN- $\gamma$ and then treated with LPS, NO production was increased about 10 folds. CM had no effect on NO production in resting mouse peritoneal macrophages compared

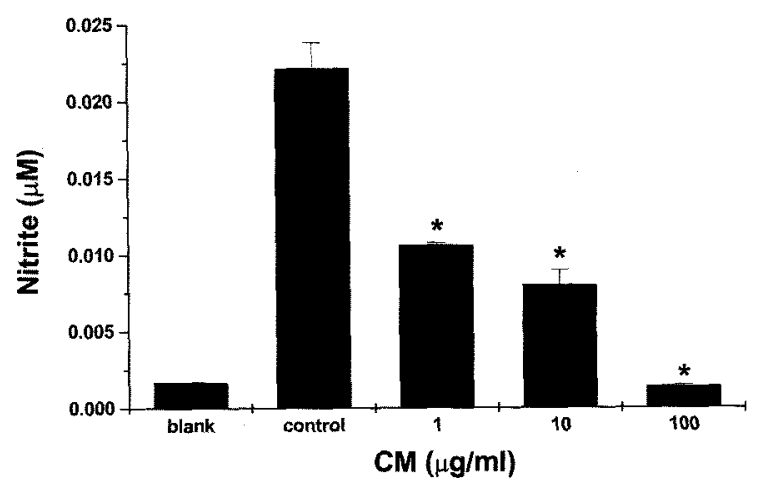

Fig. 2. Dose-dependent effects of CM on NO inhibition in rIFN- $\gamma$ and LPS-treated peritoneal macrophages. Peritoenal macrophages $\left(2.5 \times 10^{5}\right.$ cells/well $)$ were cultured with various concentration $\mathrm{CM}$. The peritoneal macrophages were then stimulated with IIFN- $\gamma(20$ $\mathrm{U} / \mathrm{ml})$ and LPS $(10 \mu \mathrm{g} / \mathrm{ml})$. After $48 \mathrm{~h}$ of culture, NO release was measured by the Griess method (nitrite). $\mathrm{NO}$ (nitrite) released into the medium is presented as the mean \pm S.E.M. of three independent experiments duplicate in each run. " $P<0.05$ compared to rIFN- $\gamma+$ LPS.
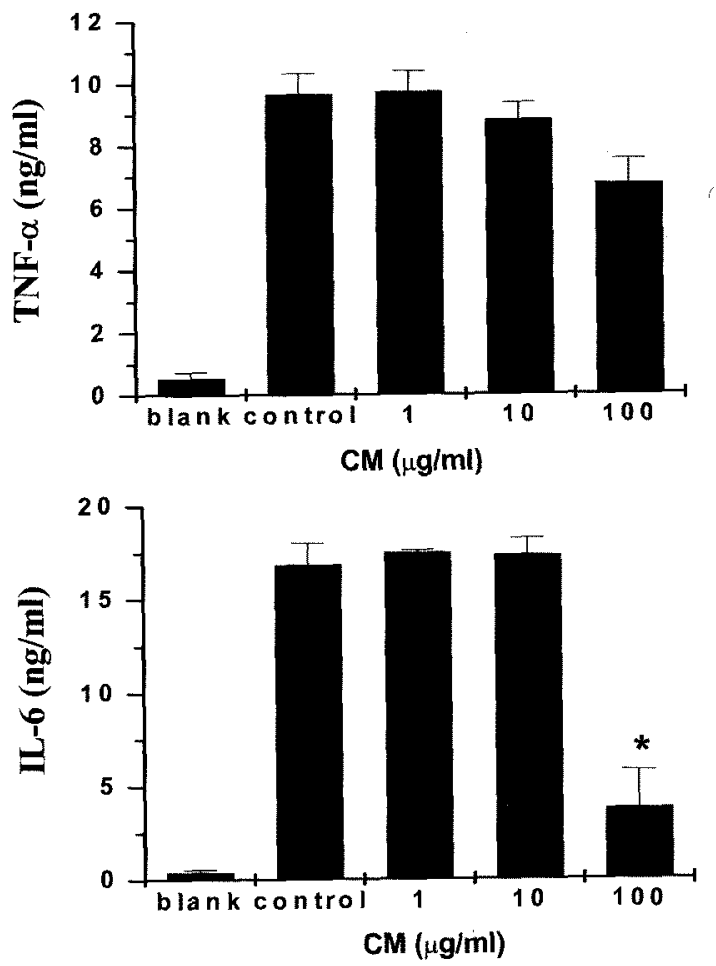

Fig. 3. Effects of CM on the rIFN-y and LPS-induced TNF- $\alpha$ and IL- 6 production in peritoneal macrophages. Peritoneal macrophages $\left(2.5 \times 10^{5}\right.$ cells/well $)$ were stimulated with various concentrations of $\mathrm{CM}$ or $\mathrm{rIFN}-\gamma$ $(20 \mathrm{U} / \mathrm{ml})$ and LPS $(10 \mu \mathrm{g} / \mathrm{ml})$ plus CM. The amount of TNF- $\alpha$ and IL- 6 secreted by peritoneal macrophages was measured by ELISA method after $24 \mathrm{~h}$ incubation. Values are the mean \pm S.E.M. of three independent experiments duplicate in each run. ${ }^{*} P<0.05$ compared to rIFN- $\gamma$ plus LPS.

to non-primed conditions. When CM was pretreated in primed cell, CM inhibits NO production dose dependently (Fig. 2).

\section{Inhibitory effects of CM on TNF- $\alpha$ and IL-6 production}

We examined the inhibitory effect of CM on LPS induced TNF- $\alpha$ and IL- 6 production. Mouse peritoneal macrophages secreted low levels of TNF- $\alpha$ and IL- 6 after $24 \mathrm{~h}$ incubation with medium alone. The basal level of TNF- $\alpha$ and IL-6 was little increased when incubated CM only. Upon IFN- $\gamma$ $(20 \mathrm{U} / \mathrm{ml})$ plus LPS $(10 \mathrm{mg} / \mathrm{ml})$ treatment for $24 \mathrm{~h}$, 


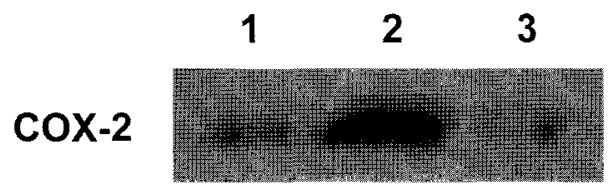

Fig. 4. Effects of CM on the expression of COX-2 by rIFN- $\gamma$ plus LPS-induced peritoneal macrophages Peritoneal macrophages $\left(5 \times 10^{6}\right.$ cells/well) were pretreated with $\mathrm{CM}$ and then stimulated for $6 \mathrm{~h}$ with $\mathrm{rIFN}-\gamma(20 \mathrm{U} / \mathrm{ml})$. The peritoneal macrophages were then stimulated with LPS $(10 \mu \mathrm{g} / \mathrm{ml})$ for $24 \mathrm{~h}$. The protein extracts were prepared, and then samples were analyzed for COX-2 expression by Western blotting as described in the method. 1, blank; 2 , rIFN- $\gamma$ + LPS; 3, CM $(100 \mu \mathrm{g} / \mathrm{ml})+$ rIFN- $\gamma$ + LPS.

TNF- $\alpha$ and IL- 6 drastically increased in these cells, and pretreatment of cells with $100 \mathrm{mg} / \mathrm{ml}$ of $\mathrm{CM}$ for $24 \mathrm{~h}$ inhibited TNF- $\alpha$ induction in mouse peritoneal macrophages (Fig. 3).

\section{Effects on expression of COX-2 protein}

We investigate the effect of the CM $(100 \mu \mathrm{g} / \mathrm{ml})$ at translational level, As shown in Fig. 4, the expression of COX-2 protein were markedly increased after IFN- $\gamma(20 \mathrm{U} / \mathrm{ml})$ plus LPS $(10 \mu \mathrm{g} / \mathrm{ml})$ challenge for $24 \mathrm{~h}$. This increased expression of COX-2 protein was significantly reduced by CM (Fig. 4).

\section{DISCUSSION}

Murine macrophage exhibits a particularly vigorous response to endotoxin, which induces production of variety of inflammatory modulators such as $\mathrm{NO}$, TNF- $\alpha$, IL- -6 and prostaglandins by inducible COX- 2 .

NO has been recognized to be an important mediator of celluar communication in several preparations such as macrophages, neutrophils, smooth muscle, autonomic nervous system, and central nervous system (Blackman et al., 2000; Koyanagi et al., 2000; Sharma et al., 2000). In this study, exposure of macrophages to IFN- $\gamma$ and LPS for $48 \mathrm{~h}$ was associated with an accumulation of nitrite in the medium, suggesting an enhanced NO production. This IFN- $\gamma$ and LPS-induced NO production was inhibited by $\mathrm{CM}$ without notable cytotoxicity.

TNF- $\alpha$ is a key mediator in immunoinflammatory diseases. Administration of TNF- $\alpha$ induces shock, whereas treatment of mice with neutralizing monoclonal antibodies anti-TNF- $\alpha$ prevents the mortality caused by LPS challenge (Remick et al., 1990). In this study, we showed that CM inhibit IFN- $\gamma$ and LPS-induced TNF- $\alpha$ production. TNF- $\alpha$ also induces the secretion of cytokine such as IL-6 and activates $T$ cells and other inflammatory cells (Vilcek and Lee, 1991). IL-6 plays an important role in the development of plasma cells and the induction of acute phase response, and it has also been demonstrated to induce neurite outgrowth in cell culture system. The secretion of IL-6 has been found to play a central role in the regulation of defense mechanism, and haematopoiesis. COX-2 plays a role in the pathophysiological processes including inflammation (Meade et al., 1993).

We documented the increased production of COX-2 protein by macrophages exposed to IFN- $\gamma$ and LPS. IFN- $\gamma$ and LPS in combination with CM led to a significant reduction in COX-2 protein expression.

Here in our study, we have shown that $\mathrm{CM}$ exerts its anti-inflammatory effects probably by the suppression of COX-2 expression, and the final result is the inhibition of NO synthesis, TNF- $\alpha$ and IL-6 release. Based on our present results, it is possible that $\mathrm{CM}$ can offer a valuable means of therapy for the treatment of inflammatory diseases by attenuating IFN- $\gamma$ and LPS-induced NO synthesis and pro-inflammatory cytokine and controlling of COX-2 expression.

\section{ACKNOWLEDGEMENTS}

This work was supported by the Korea Research Foundation Grant funded by the Korean Government (MOEHRD) (the Center for Healthcare Technology Development, Woosuk University, chonbuk, 565-701, Republic of Korea). 


\section{REFERENCES}

Adams DO, Hamilton TA. (1984) The cell biology of macrophage activation. Annu. Rev. Immunol. 2, 283318.

Blackman DJ, Morris-Thurgood JA, Atherton J, Ellis G.R, Anderson RA, Cockcroft JR, Frenneaux MP. (2000) Endothelium-derived nitric oxide contributes to the regulation of venous tone in humans. Circulation 18, 165-170.

Chung HS, Jeong HJ, Hong SH, Kim MS, Kim SJ, Song BK, Jeong IS, Lee EJ, Ahn JW, Baek SH. Kim HM. (2002) Induction of nitric oxide synthase by Oldenlandia diffusa in mouse peritoneal macrophages. Biol. Pharm. Bull. 25, 1142-1146.

Evans CH. (1995) Nitric oxide: what role does it play in inflammation and tissue destruction? Agents Actions Supplement 47, 107-106.

Gorman JD, Sack KE, Davis JC. (2002) Treatment of ankylosing spondylitis by inhibition of tumor necrosis factor alpha. New Engl. J. Med. 346, 1349-1356.

Jeong HJ, Chung HS, An HJ, Kim JB, Lee EM, Park EJ, Jang CH, Hong SH, Kim HM. (2003) Immuneenhancement effect of the herbal combination Allergina. Clin. Chim. Acta 337, 77-84.

Jiangsu New Medical College. (1977) "The Dictionary of Chinese Medicine" (Zhong Tao Da ci Dian), Shanghai, Science and Technique Press, Shanghai, pp. 2008.

Kanazawa K., Kawasaki H, Samejima K, Ashida H, Danno G. (1995) Specific desmutagen (antimutagen) in oregano against a dietary carcinogen, Trp-P-2, are galangin and quercetin. J. Agric. Food Chem., 43, 404-409.

Koyanagi M, Egashira K, Kubo-Inoue M, Usui M, Kitamoto S, Tomita H, Shimokawa H, Takeshita A. (2000) Role of transforming growth factor-beta1 in cardiovascular inflammatory changes induced by chronic inhibition of nitric oxide synthesis. Hypertension 35, 86-90.
Liew FY. (2003) The role of innate cytokines in inflammatory response. Immunol. Lett. 85, 131-134.

Meade EA, Smith WL, DeWitt DL. (1993) Differential inhibition of prostaglandin endoperoxide synthase (cyclooxygenase) isozymes by aspirin and other non-steroidal anti-inflammatory drugs. J. Biol. Chem. $268,6610-6614$.

O'Shea JJ, Ma A, Lipsky P. (2002) Cytokines and autoimmunity. Nat. Rev. Immunol. 2, 37-45.

Park JG., Park JC, Hur JM, Park SJ, Choi DR, Shin DY, Park KY, Cho HW, Kim MS. (2000) Phenolic compounds from Orostachys japonicus having antiHIV-1 protease activity. Nat. Pro. Sci., 6, 117-121.

Remick DG, Strieter R.M, Eskandari MK, Nguyen DT, Genord MA, Raiford CL, Kunkel SL. (1990) Role of tumor necrosis factor-alpha in lipopolysaccharideinduced pathologic alterations. Am. J. Pathol. 136, 49-60.

Schimmer BP, Parker KL. (2001) Adrenocorticotropic hormone; adrenocortical steroids and their synthetic analogs; inhibitors of the synthesis and actions of adrenocortical hormones. In: Hardman, J. G., Limbird, L.E., Goodman Gilman, A. (Eds.), The Pharmacological Basis of Therapeutics 10th ed. McGraw-hill, New York, 1649-1677.

Sharma R, Coats AJ, Anker SD. (2000) The role of inflammatory mediators in chronic heart failure: cytokines, nitric oxide, and endothelin-1. Int. J. Cardiol. 15, 175-186.

Stadnyk AW, Gillan TL, Anderson R. (1997) Respiratory syncytial virus triggers synthesis of IL-6 in BALB/C mouse alveolar macrophages in the absence of virus replication. Cell. Immunol. 176, 122-126.

Thiemermann C, Vane J. (1990) Inhibition of nitric oxide synthesis reduces the hypotension induced by bacterial lipopolysaccharides in the rat in vivo. Eur. J. Pharmacol. 182, 591-595.

Vilcek J, Lee TH. (1991) Tumor necrosis factor. New insights into the molecular mechanisms of its multiple actions. J. Biol. Chem. 266, 7313-7316. 